\title{
Az alapellátásban kezelt COVID-19-fertőzött gyermekek tünettani és epidemiológiai jellemzői
}

\author{
Karászi Éva dr. ${ }^{1}$. Onozó Beáta dr. ${ }^{2}$ - Sütő Adrienn dr. ${ }^{3}$ \\ Kutas Katalin dr. ${ }^{4}$ - Szalóczi Beáta dr. ${ }^{5}$ - Laczkovszki Melinda dr. ${ }^{6}$ \\ Demeter Gabriella dr. ${ }^{7}$ - Kovács Fruzsina dr. ${ }^{8}$ - Tordas Dániel dr. ${ }^{9}$ \\ Dalloul Hicham dr. ${ }^{10}$ - Világos Eszter dr. ${ }^{11}$ - Erlaky Hajna dr. ${ }^{12}$
}

${ }^{1}$ Budapest Főváros XXII. kerület - Budafok-Tétény Önkormányzata, 3. sz. házi gyermekorvosi körzet, Budapest

${ }^{2}$ Miskolc Megyei Jogú Város Önkormányzata, 32. sz. házi gyermekorvosi körzet, Miskolc

${ }^{3}$ Páty Község Önkormányzata, betöltetlen 2. sz. házi gyermekorvosi körzet (helyettesítéssel ellátott), Páty

${ }^{4}$ Budapest Főváros XI. kerület - Újbuda Önkormányzata, 17. sz. házi gyermekorvosi körzet, Budapest

${ }^{5}$ Budapest Főváros I. kerület - Budavári Önkormányzat, Markovits utcai házi gyermekorvosi rendelő, Budapest

${ }^{6}$ Budapest Főváros XXII. kerület - Budafok-Tétény Önkormányzata, 1. sz. házi gyermekorvosi körzet, Budapest

${ }^{7}$ Budapest Fóváros XVI. Kerületi Önkormányzat, 3. sz. házi gyermekorvosi körzet, Budapest

${ }^{8}$ Budapest Főváros XVII. kerület - Rákosmente Önkormányzata, 15. sz. házi gyermekorvosi körzet, Budapest

${ }^{9}$ Budakalász Város Önkormányzata, 2. sz. házi gyermekorvosi körzet, Budakalász

${ }^{10}$ Budakalász Város Önkormányzata, 1. sz. házi gyermekorvosi körzet, Budakalász

${ }^{11}$ Gyenesdiás Nagyközség Önkormányzata, Gyermekorvosi Rendelő, Gyenesdiás

${ }^{12}$ Budapest Fôváros XII. kerület - Hegyvidéki Önkormányzat, 7. sz. házi gyermekorvosi körzet, Budapest

Bevezetés: A COVID-19-pandémia kapcsán számos tanulmány vizsgálta a tünetek gyakoriságát és a járványterjedés jellemzőit gyermekkorban, kevés azonban az alapellátás adatait összefoglaló publikáció. Közleményünkben 12 házi gyermekorvosi praxis 545 SARS-CoV-2-fertőzött betegének adatait elemeztük a 2. $(\mathrm{n}=293)$ és a 3. $(\mathrm{n}=252)$ járványhullámban.

Célkitüzés: A gyermekkori fertőzések tünettanának és epidemiológiai jellemzőinek összehasonlítása korcsoportok és járványhullámok között.

Módszer: Valamennyi alapellátó praxis egységes retrospektív adatgyüjtést végzett ugyanazon paraméterek regisztrálásával.

Eredmények: A 10 év alatti betegekben a láz, a nátha és a köhögés dominált (30-50\%), míg a 10 év felettiekben magas arányban regisztráltunk általános tüneteket is (30-40\% fejfájás, gyengeség, szaglászavar). A 2. hullámban a 11-18 évesek $(68 \%)$, a 3 . hullámban a 0-10 évesek (53\%) voltak többségben. A 3. hullámban szignifikánsan emelkedett a légúti tünetek előfordulása, az általános tünetek gyakorisága jelentősen csökkent, és szignifikánsan nőtt a családon belüli expozíció aránya (36\% vs. 58\%) a 2. hullámmal összehasonlítva. A gyermekról családtagra történő továbbterjedés $24 \%$ és $16 \%$ volt a két járványhullámban, és mértékét az életkor befolyásolta.

Megbeszélés: A klinikai kép az életkorral és a feltételezett vírusvariánssal mutatott összefüggést: 10 év alatt a légúti tünetek domináltak, 10 év felett szignifikánsan több általános tünetet regisztráltunk a 0-10 évesekhez képest. A 3. járványhullámban az alfa-variáns terjedésével gyakoribbá váltak a légúti tünetek, az iskolabezárások következtében megváltozott az életkori megoszlás, és megemelkedett a családi expozíció okozta fertózések aránya. A fertőzés továbbadása háztartáson belül mindkét hullámban alacsony maradt.

Következtetés: A COVID-19 klinikai megjelenését és terjedési jellemzőit jelentősen befolyásolta az érintett gyermekpopuláció életkori összetétele, a cirkuláló vírusvariáns és az aktuális korlátozó intézkedések.

Orv Hetil. 2021; 162(44): 1751-1760.

Kulcsszavak: COVID-19, gyermek, tünetek, transzmisszió 


\section{Clinical and epidemiological characteristics of pediatric COVID-19 patients in a community-based study}

Introduction: During the COVID-19 pandemic, a large number of publications examined the frequency of symptoms and the mode of transmission in childhood but only a few community-based studies have been published. In our paper, 545 pediatric COVID-19 patients' data were collected by 12 primary care pediatricians in the second $(\mathrm{n}=$ $293)$ and third $(\mathrm{n}=252)$ waves of the pandemic.

Objective: To compare the frequency of symptoms and household transmission in different age groups and between the two waves.

Method: Patients' data and disease characteristics were recorded retrospectively in the same manner by all participating pediatricians.

Results: In patients of $<10$ years of age, fever, rhinorrhea and cough were registered the most frequently $(30-50 \%)$, in contrast to patients of $>10$ years, where high frequency of general symptoms was found $(30-40 \%$ headache, weakness, anosmia). In the third wave, the ratio of the age group $11-18$ years declined from $68 \%$ to $47 \%$, the frequency of respiratory symptoms increased significantly, while the ratio of general symptoms decreased. Household exposition was more frequent in the third wave $(36 \%$ vs. $58 \%)$, while the transmission rate from children to family members was $24 \%$ and $16 \%$, respectively, and it varied with age.

Discussion: Clinical manifestation showed relation to age and virus variant: the older age associated with higher frequency of general symptoms and the spread of the alpha variant led to the predominance of respiratory symptoms over general complaints. Prolonged school closures affected the age distribution and increased the frequency of household exposition. Secondary household transmission remained low.

Conclusion: Clinical and epidemiological characteristics of pediatric COVID-19 disease were highly influenced by age, dominant virus variant and mitigation measures.

Keywords: COVID-19, children, symptoms, transmission

Karászi É, Onozó B, Sütő A, Kutas K, Szalóczi B, Laczkovszki M, Demeter G, Kovács F, Tordas D, Dalloul H, Világos E, Erlaky H. [Clinical and epidemiological characteristics of pediatric COVID-19 patients in a communitybased study]. Orv Hetil. 2021; 162(44): 1751-1760.

(Beérkezett: 2021. július 25.; elfogadva: 2021. augusztus 15.)

\section{Rövidítések}

$\mathrm{CDC}=($ Centers for Disease Control and Prevention $)$ Amerikai Járványügyi és Betegségmegelőzési Központ; COVID-19 = (coronavirus disease 2019) koronavírus-betegség 2019; ECDC $=($ European Centre for Disease Prevention and Control $)$ Európai Betegségmegelőzési és Járványügyi Központ; MIS-C $=($ multisystem inflammatory syndrome - children $)$ sokszervi gyulladásos tünetegyüttes - gyermekekben; NS = nem szignifikáns; PCR = (polymerase chain reaction $)$ polimeráz-láncreakció; SARS-CoV-2 = (severe acute respiratory syndrome coronavirus 2 ) súlyos akut légúti tünetegyüttest okozó koronavírus-2

A 2019 decemberében azonosított új típusú koronavírus (SARS-CoV-2) által okozott COVID-19-ről egyre több ismerettel rendelkezünk. Számos tanulmány vizsgálta a betegség klinikai manifesztációit, patomechanizmusát, a járványterjedés jellemzőit és a korlátozó intézkedések hatásait. A gyermekgyógyászat terén szerényebb a publikációk listája, amit a gyermekkorban észlelt enyhébb lefolyás és a fertőzöttek relatíve alacsony aránya magyarázhat. A CDC és az ECDC adatai alapján a 2. és a 3. hullámban a fertőzöttek 10-15\%-a került ki a 0-18 éves korosztályból [1, 2]. Ez elmarad a korcsoport kb. 20\%os arányától, aminek elsődleges oka az enyhe és tünetmentes esetek magas aránya lehet, de az óvoda- és isko- labezárások ténylegesen csökkenthették a betegség gyermekkori előfordulását [3-5]. A gyermekkori klinikai kép jelentősen különbözik a felnőttekben leírtaktól, a betegség az esetek többségében felső légúti megbetegedés formájában zajlik. Az eddigi adatok alapján a láz és a köhögés aránya 35-50\%; minden egyéb légúti és általános tünet gyakoriságát ennél alacsonyabbnak találták, bár amerikai adatok szerint tinédzserekben a fejfájás és a myalgia előfordulása is eléri a 30-40\%-ot [6]. Súlyosabb kimenetellel az 1 év alatti korosztályban és az alapbetegséggel rendelkezőkben kell számolni (obesitas, diabetes mellitus, krónikus tüdő- és szívbetegségek, anyagcsere-, neurológiai és genetikai betegségek, immunszupprimált állapotok). A gyermekkori hospitalizáció aránya 2-4\%, ezen belül intenzív ellátást a betegek $\mathrm{kb}$. harmada igényel, és a halálozás $0,1 \%$ körüli [7].

A fertőzés háztartáson belüli és közösségi terjedését számos tanulmány vizsgálta a gyermekpopulációban $[8$, 9]. A betegség családon belüli akvirálása terén az eredmények igen nagy szórást mutatnak, ezek alapján a gyermekek 4-50\%-a fertőződött meg háztartáson belül, a vizsgálat típusától függően. A családon belüli továbbterjedést (szekunder transzmisszió) tekintve az arányok szintén nagyon változók, a legtöbb tanulmány szerint azonban a kisgyermekek ritkábban fertőzik meg szülei- 
ket, mint az iskoláskorúak [10, 11]. A fertőzés terjesztésében a tünetmentes gyermekeknek is szerepük lehet, amit a leginkább a családi esethalmozódások igazolnak. A COVID-19-cel kapcsolatos publikációk többsége a kórházi sürgősségi osztályokon megforduló, illetve hospitalizációt igénylő betegek eredményeit dolgozza fel.

Közleményünkben, Magyarországon elsőként, az alapellátásban diagnosztizált és otthonukban kezelt 0-18 éves COVID-19-betegek adatait mutatjuk be a tünettan, az expozíció (kontaktus) és a továbbfertőzés szempontjából, mindezt korosztályonként és járványhullámonként elemezve, és a nemzetközi irodalomban elérhető adatokkal összevetve.

\section{Betegek és módszer}

Retrospektív tanulmányunkban 12 magyarországi házi gyermekorvosi praxisban COVID-19-betegséggel diagnosztizált gyermekek adatait gyưjtöttük össze és dolgoztuk fel. Valamennyi orvos a Biztos Kezek Alapellátó Gyermekorvosok Társaságának tagja.

Vizsgálati idôszak: A járvány 2. (2020. szeptember 1.-2021. január 15.) és 3. (2021. február 1.-május 31.) hullámában diagnosztizált betegeket vontuk be a vizsgálatba.

Betegszám és életkor: Összesen 545 beteg adatait dolgoztuk fel (2. hullám: $\mathrm{n}=293,3$. hullám: $\mathrm{n}=252)$, a betegek a 0-18 éves korosztályba tartoztak.

Teriuleti megoszlás: A betegek Budapest és az agglomeráció (Budakalász, Páty, Zsámbék, Telki, Budakeszi, Érd,
Szigethalom, Gyömrő, Csömör, Pécel, Albertirsa), Miskolc, továbbá Zala megyei települések (Gyenesdiás, Vonyarcvashegy, Keszthely, Balatongyörök, Cserszegtomaj) lakói.

Az adatok regisztrálása: A betegségre vonatkozó adatokat valamennyien egységesen rögzítettük, meghatározott paraméterek alapján, anonim módon (életkor, tünetek, kimenetel, kontaktus, továbbfertőzés).

Tesztelési stratégia: A koronavírus-fertőzésre gyanús esetekben a tesztkérést a tünetek és/vagy a kontaktus megléte alapján kezdeményeztük az Országos Mentőszolgálatnál. A Magyarországon aktuálisan érvényben levő eljárásrendnek megfelelően kezdetben kizárólag PCR-vizsgálat történt. 2020 novemberétől első lépésként antigéngyorstesztet végeztek, amelynek negatív eredménye esetén került sor PCR-vizsgálatra.

Beválasztási kritérium: A diagnózist szinte minden esetben pozitív PCR-teszt vagy pozitív antigéngyorsteszt alapján állítottuk fel. A 2 . hullámban $5 / 293$ esetben, a 3 . hullámban $8 / 252$ esetben a szoros kontaktus (családi pozitivitás) és/vagy típusos tünetek alapján történt a betegség diagnosztizálása (ebból 2 esetben kétes, 3 esetben negatív volt a PCR eredménye, 8 esetben nem történt tesztelés). Kizárási kritérium az életkori megfelelőségen (0-18 év) kívül nem volt.

Gyógyulttá nyilvánitás: Az Eljárásrendnek megfelelően a beteget a tünetek kezdetétől számított minimum 10 . nap után és 3 tünetmentes nap megléte után tekintettük gyógyultnak. „Felszabadító” PCR-vizsgálat ezzel a céllal nem történt háziorvosi kezdeményezésre.

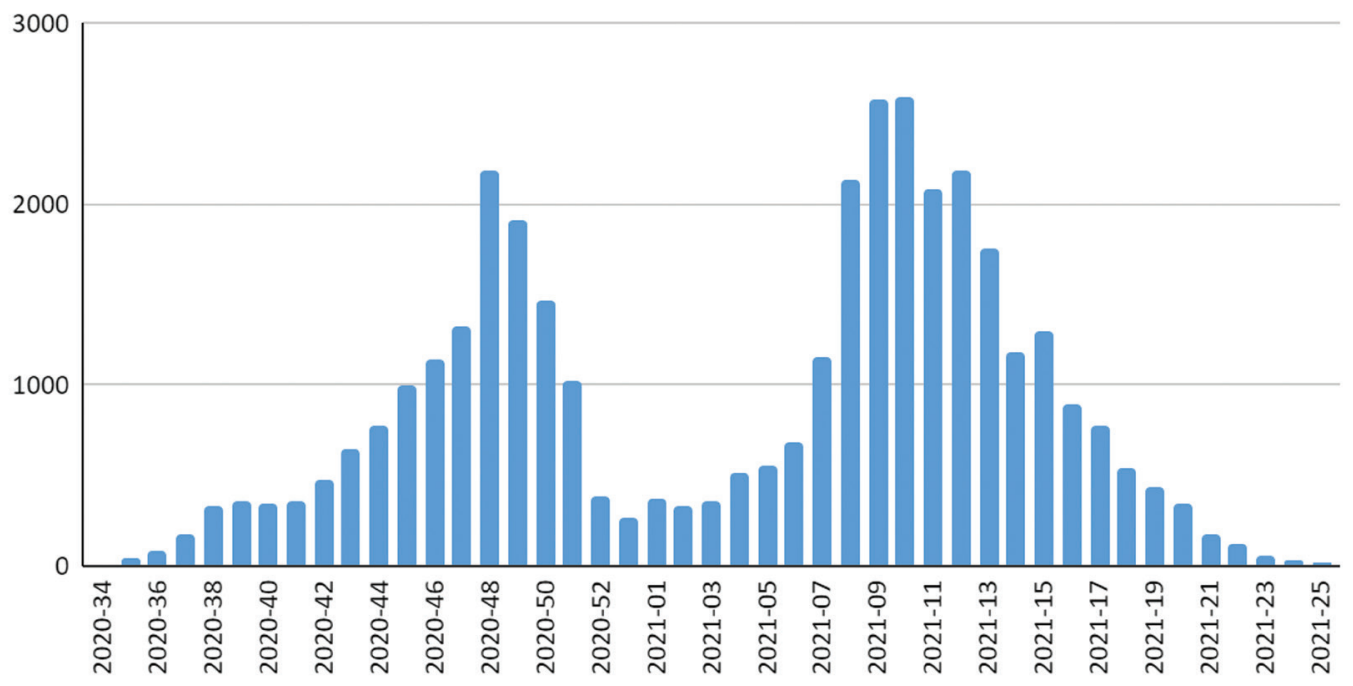

Középiskolák zárva: 2020. 11. 16.-2021. 05. 10.

Általános iskolák és óvodák zárva: 2021. 03. 08.-2021. 04. 19. 
A betegadatokat retrospektív módon és teljesen anonim rendszerben dolgoztuk fel, így etikai jóváhagyásra nem került sor.

Statisztikai analizis: A két járványhullám eredményeinek és az életkori csoportok adatainak összehasonlításához a Fisher-féle egzakt tesztet használtuk (GraphPad Prism 9.1.2, group comparison; GraphPad Software LLC, San Diego, CA, USA). Az eltérést $\mathrm{p}<0,05$ esetén tekintettük szignifikánsnak.

\section{Eredmények}

\section{Demográfiai/epidemiológiai adatok}

A fenti időszakra vonatkozó hazai esetszámokat a 15 év alatti gyermekek körében az 1 . ábra foglalja össze heti bontásban, az ECDC-nek jelentett adatok alapján [2]. Anyagunkban a 2. hullámban $(\mathrm{n}=293)$ az átlagéletkor

1. táblázat |A betegpopuláció epidemiológiai jellemzői és a tesztelési eredmények

\begin{tabular}{|c|c|c|}
\hline & $\begin{array}{l}\text { 2. hullám } \\
\text { 2020.09.01.- } \\
\text { 2021.01. } 15 .\end{array}$ & $\begin{array}{l}\text { 3. hullám } \\
\text { 2021.02.01.- } \\
\text { 2021.05.31. }\end{array}$ \\
\hline Betegszám (n) & 293 & 252 \\
\hline Átlagéletkor & 11,9 év & 9,5 év \\
\hline 0-5 év & $10 \%$ & $26 \%$ \\
\hline 6-10 év & $22 \%$ & $27 \%$ \\
\hline 11-14 év & $36 \%$ & $29 \%$ \\
\hline 15-18 év & $32 \%$ & $17 \%$ \\
\hline Férfi vs. nő arány & $55 \%$ vs. $45 \%$ & $47 \%$ vs. $53 \%$ \\
\hline Alapbetegség* & $11 \%$ & $7,5 \%$ \\
\hline Versenyszerüen sportolók & $5,2 \%$ & $4,4 \%$ \\
\hline Hospitalizáció & 1 beteg & 0 beteg \\
\hline $\begin{array}{l}\text { Szövődmény } \\
\text { ('long' COVID, MIS-C) }\end{array}$ & $0,7 \%$ & $3 \%$ \\
\hline $\begin{array}{l}\text { A fertőzöttek aránya átlagosan } \\
\text { a praxis létszámán belül }\end{array}$ & $2,8 \%$ & $3,4 \%$ \\
\hline $\begin{array}{l}\text { A pozitív tesztek aránya a kért } \\
\text { tesztek között }\end{array}$ & $28 \%$ & $33 \%$ \\
\hline $\begin{array}{l}\text { A pozitív antigéngyorstesztek } \\
\text { aránya a fertőzöttek között }\end{array}$ & $31 \%$ & $44 \%$ \\
\hline $\begin{array}{l}\text { A tünetek kezdete és a tesztelés } \\
\text { között eltelt idő }\end{array}$ & 3,9 nap & 3 nap \\
\hline
\end{tabular}

*Az alapbetegségek az alábbiak voltak a 2. hullámban (zárójelben az esetszámok): allergia (5), asthma (7), epilepsia (4), immunszupprimált állapot (2), elhízás (4), szívbetegség (2), coeliakia (1), hypertonia polycystás ovarium szindrómával (1), diabetes mellitus (1), cerebralis paresis (1), spondyloepiphysealis dysplasia (1), figyelemzavar hiperaktivitással (1), autizmus (1), hydronephrosis (1). A 3. hullámban: asthma (8), diabetes mellitus (1), inzulinrezisztencia (2), anorexia (1), Sotosszindróma (1), mentális visszamaradottság (1), biliaris atresia (1), obesitas 1), vitium (1), Jacobsen-szindróma (1), vashiányos anaemia (1)

COVID = koronavírus-betegség; MIS-C = sokszervi gyulladásos tünetegyüttes - gyermekekben
11,9 év (4 hó-18 év) volt. Életkori megoszlás: 0-5 év: 10\%, 6-10 év: 22\%, 11-14 év: 36\%, 15-18 év: 32\%. Mindössze 4 gyermek volt 1 év alatti csecsemő. A 3. hullámban $(\mathrm{n}=252)$ az átlagéletkor 9,5 év (0-18 év) volt, és a következó életkori megoszlást találtuk: 0-5 év: 26\%, 6-10 év: 27\%, 11-14 év: 29\%, 15-18 év: 17\%. 7 gyermek volt 1 év alatti, köztük egy újszülött (1. táblázat).

A nemek megoszlása nem mutatott érdemi különbséget: a 2. hullámban a férfi-nó arány $55 \%$ vs. $45 \%$, a 3 . hullámban $47 \%$ vs. $53 \%$ volt (összesítve $51 \%$ vs. $49 \%$ ). Alapbetegséget a 2 . hullámban a betegek $11 \%$-ában regisztráltunk, a 3 . hullámban a fertőzöttek 7,5\%-ának volt ismert alapbetegsége (a részletes leírás az 1. táblázatban látható).

\section{A tesztelésre vonatkozó adatok}

Az esetek közel 90\%-ában telemedicina segítségével történt a tesztkérés indikálása és a betegek követése. A 12 praxis adatait átlagolva a 2. hullámban a praxisba tartozó gyermekek $2,8 \%$-a, míg a 3 . hullámban a praxisok betegeinek 3,4\%-a volt igazoltan COVID-19-fertőzött. A legmagasabb arányok Budapesten adódtak (azon belül is a pesti kerületekben), míg a vidéken és az agglomerációban észlelt gyakoriság alacsonyabb volt.

6 praxis adatai alapján a 2 . hullámban a kért tesztek 28\%-a adott pozitív eredményt, míg a 3. járványhullámban a tesztek 33\%-a mutatott pozitivitást. A fertőzöttek között a pozitív antigéngyorstesztek aránya a 2. hullámban $31 \%$ volt ( $55 / 176$, novembertől regisztrálva), míg a 3. hullámban ez az arány 44\%-ra emelkedett (110/252) (1. táblázat).

\section{Transzmisszió: kontaktus/expozició és a betegség továbbterjesztése}

A 2. hullámban a betegek 58\%-ában regisztráltunk kontaktust igazoltan COVID-19-fertőzött beteggel (170/293 esetben), ezen belül az esetek közel kétharmadában családon belüli expozíció állt fenn, így a gyermekek 36\%-a fertőződött meg családi kontaktust követően (105/292 eset). Az iskolai/óvodai kontaktusok aránya $23 \%$ volt. A 3 . hullámban a betegek $68 \%$-ánál volt kimutatható kontaktus az anamnézisben (173/252 beteg); többségüknél háztartáson belüli expozíció igazolódott (144/252), így az összes beteg 58\%-a fertőződött meg családtagok által, döntően a szülőktől. A családi expozíció aránya szignifikánsan magasabb volt a 3. hullámban $(36 \%$ vs. $58 \%, \mathrm{p}<0,0001)$, az iskolai/óvodai expozícióé pedig szignifikánsan alacsonyabb $(23 \%$ vs. $12 \%, \mathrm{p}=$ $0,0008)$.

Betegeink a 2. hullámban 72/293 (24\%) esetben adták tovább a fertőzést családon belül, a 3 . hullámban alacsonyabb arányban, $41 / 252$ (16\%) esetben fertőzte meg a beteg gyermek (index case) a családtagokat $(\mathrm{p}=0,013)$ (2. ábra). 


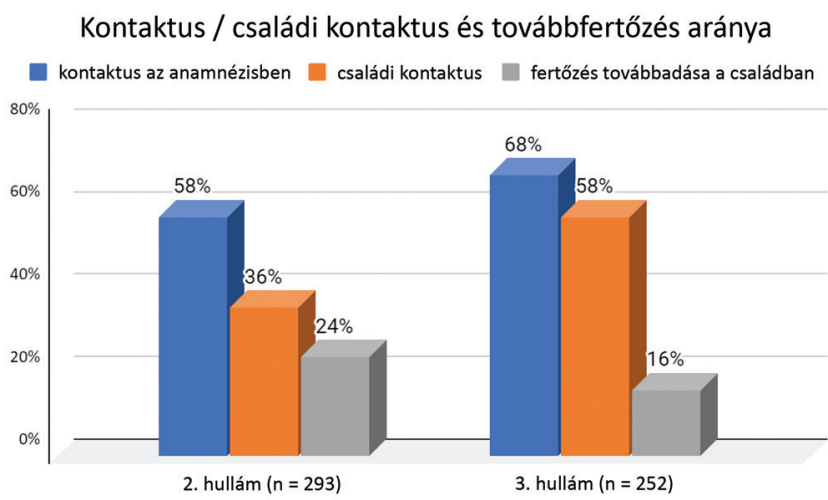

2. ábra

Az ismert kontaktus és a szekunder transzmisszió gyakoriságá nak összehasonlítása a 2. $(\mathrm{n}=293)$ és a 3. $(\mathrm{n}=252)$ hullámban

\section{Tünettani jellemzők}

A 2. hullámban $(\mathrm{n}=293)$ a betegek harmadában jelentkezett a járvány kezdetén klasszikus tünetként leírt láz és/vagy köhögés (31\% és 28\%), míg a nehézlégzés aránya mindössze 3\% volt. Emellett a leggyakoribb tünet a nátha $(36 \%)$ és a subfebrilitas $(30 \%)$ volt, melyet fóleg kisgyermekekben figyeltünk meg; a nagyobbakban a fejfájás $(35 \%)$ és a gyengeség $(31 \%)$ volt a vezető tünet. Torokfájás és anosmia az esetek mintegy negyedében jelentkezett (23\% és 27\%). Enteralis tünet 9\%-ban, bőrtünet 2\%-ban fordult elő. A tünetek időtartama átlagosan 5,3 nap volt ( $\min .:$ I nap-max.: 20 nap).

A 3. hullámban $(n=252)$ a láz/hőemelkedés továbbra is az esetek harmadában volt megfigyelhetô. Szignifikánsan emelkedett a köhögés ( $28 \%$ vs. $38 \% \mathrm{p}=0,022)$, a náthás tünetek $(36 \% v s .50 \%, \mathrm{p}=0,003)$, és a torokfájás $(23 \%$ vs. $33 \%, \mathrm{p}<0,0001)$ aránya a 2 . hullámhoz képest. Csökkent a gyengeség és a fejfájás előfordulása $(31 \%, v s$. $24 \%$ és $35 \%$ vs. $27 \%$, NS), és szignifikánsan ritkábban jelentkezett szaglászavar $(27 \%$ vs. $8 \%, \mathrm{p}<0,0001)$. Az enteralis tünetek gyakorisága nem változott érdemben, $11 \%$ volt. A tünetek időtartama hosszabb volt, átlagosan 6,2 nap (min.: 2 nap-max.: 27 nap). A tünetmentesek aránya mindkét időszakban $4 \%$ volt (3. ábra).

A diagramon nem részletezett, nem típusos COVID19-tünetek a 2. hullámban a betegek 13\%-ában, a 3. hullámban a $10 \%$-ában fordultak elő, a leggyakoribb a mellkasi fájdalom, a palpitatio, a szédülés, az ízületi fájdalom, a szem- és fülfájdalom, a conjunctivitis, a hidegrázás és a rekedtség volt.

\section{Kimenetel}

A 2. hullámban 1 beteg kivételével valamennyi gyermek az otthonában gyógyult, tüneti kezelés mellett. A kórházba kerülő betegben neurológiai alapbetegség mellett grand mal típusú convulsio jelentkezett, mely miatt intenzív osztályos ellátást igényelt. A 3. hullámban 2 gyermeket vizsgáltak kórházban, náluk azonban hospitalizáció nem vált szükségessé. Így összességében a hospitalizáció aránya anyagunkban $1 / 545(0,18 \%)$, a halálozás $0 \%$ volt.

\section{Szövödmények ('long' [hosszú] COVID, MIS-C)}

A 2. hullámban a gyógyulás utáni idôszakban 9 betegben észleltünk szövődményt $(0,7 \%)$, melyek az alábbi kórképek/tünetek voltak (zárójelben az esetszámok): gyermekkori sokszervi gyulladásos tünetegyüttes (MIS-C) (2), elhúzódó fáradékonyság (1), tartós fejfájás ( 1 ), elhúzódó szédülés ( 1 ), elhúzódó köhögés (1), tartós mellkasi fájdalom (1), lábzsibbadás ( 1 ).

A 3. hullámban mintegy négyszer annyi, 3\% volt a felismert szövődmények aránya: intenzív osztályos kezelést igénylő MIS-C (1), poszt-COVID gyulladásos tünetegyüttes, amely a MIS-C kritériumait nem merítette ki (2), továbbá elhúzódó fejfájás (1), ízületi fájdalom (1), koncentrációs zavar, fáradékonyság (2), elhúzódó köhögés (1) és ismert diabeteses betegben nehezen normalizálható tartós hyperglykaemia (1).

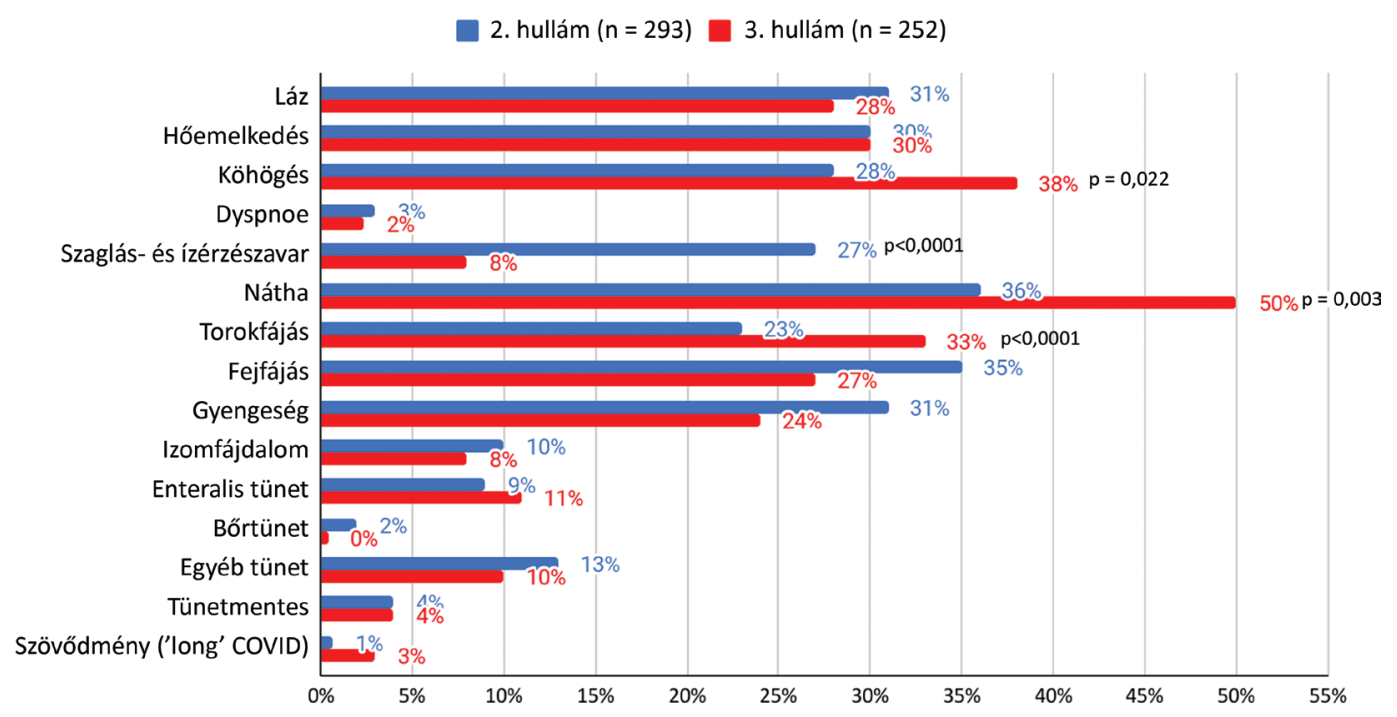

3. ábra |A tünetek összehasonlítása a 2. és a 3. hullámban $(n=293$ és $n=252)$ (szignifikáns különbség esetén a p-értéket is feltüntettük) 


\section{Regionális sajátosságok}

A tünettani jellemzőket az ország alábbi 4 régiójában hasonlítottuk össze: Budapest, Pest megyei települések, Miskolc és Balaton-felvidék. A 2. hullámban a klinikai kép a budapesti és a balatoni települések között mutatott hasonlóságot, mely a populáció átfedéséből/ingázásából is adódhatott. A 3. hullámban a tünetek gyakorisága a budapesti és a miskolci betegek vonatkozásában volt hasonló, a kisebb településekkel szemben. A fejfájás és az enteralis tünetek mindkét hullámban Budapesten jelentkeztek a leggyakrabban. Összességében azonban a betegség időtartama és klinikai megjelenése nem mutatott egyértelmú statisztikai korrelációt a település méretével és a lakosságszámmal.

\section{Tünettani jellemzők társbetegségek esetén}

Az alapbetegségben szenvedők tünettanát összevetettük az alapbetegséggel nem rendelkező gyermekekével. A tünetek gyakorisága az enteralis tünetek megjelenésében mutatott szignifikáns különbséget: az alapbetegséggel rendelkezőkben kétszer gyakrabban jelentkezett hányás, hasmenés vagy hasfájás ( $9 \%$ vs. 18\%), továbbá a társbetegséggel rendelkezőkben magasabb volt az egyéb tünetek előfordulása is (hidegrázás, szemfájdalom, fülfájás, palpitatio, hyperglykaemia, convulsio). A többi tünet előfordulása szinte megegyezett a két csoportban. Kiemelendő azonban, hogy az egyetlen, intenzív osztályos kezelést igénylő primer COVID-19-infekció (nem MISC) neurológiai alapbetegség talaján alakult ki.

\section{Korcsoportok szerinti eredmények}

A kontaktus gyakoriságát, a továbbfertőzés arányát és a tünetek megoszlását a 0-5, 6-10,11-14 és 15-18 éves korosztályban külön-külön megvizsgáltuk, keresve a korspecifikus jellemzőket.

\section{A kontaktus és a továbbfertözés életkori sajátosságai}

2. hullám, 0-5 év: az esetek több mint felében (55\%) családi kontaktus (szülők) volt a fertőzés forrása, és ez a korosztály csak 14\%-ban adta tovább családon belül a fertőzést. 6-10 és 11-14 év: az esetek mintegy harmadában, 34\%-ban és 38\%-ban volt családi kontaktus a fertőzés forrása, azaz az általános iskolás korosztályban az esetek kétharmadában közösségi expozíció okozta a fertőzést. A 6-10 évesek magas arányban, 41\%-ban, a 1114 évesek 25\%-ban adták tovább a fertőzést háztartáson belül. 15-18 év: 29\%-uk fertőződött meg családtagtól, azaz a középiskolások csaknem háromnegyede a saját korosztálya körében kapta el a fertőzést, és csak 20\%-uk adta tovább a családban a betegséget (4. ábra).

3. hullám, 0-5 év és 6-10 év: az esetek közel kétharmadában, 60\%-ban, illetve 63\%-ban családi kontaktus volt a fertőzés forrása (85\%-ban szülők, kisebb részben testvérek). A betegség továbbterjesztése családon belül 1415\%-ban volt igazolható. A 10 év feletti betegekben az esetek kb. felében regisztráltunk családi expozíciót (51\% és 56\%), és a betegek mindössze 14\%-a és 7\%-a adta tovább a fertőzést családtagoknak (5. ábra).

\section{A tünetek életkor szerinti gyakorisága a 0-10 éves és 11-18 éves korcsoportokban}

A tünetek időtartama minden korosztályban hosszabb volt a 3. hullámban, mint a 2. hullámban. A 10 év felettiekben mindkét hullámban hosszabban zajlott a betegség, mint a fiatalabbakban. A 10 év alattiakban a láz/ hőemelkedés, a nátha és a köhögés dominált, minden egyéb tünet aránya alacsony volt $(<25 \%)$. A 10 év felettiekben a légúti tünetek mellett a betegek 30-40\%-ában többféle általános tünet is jelentkezett.

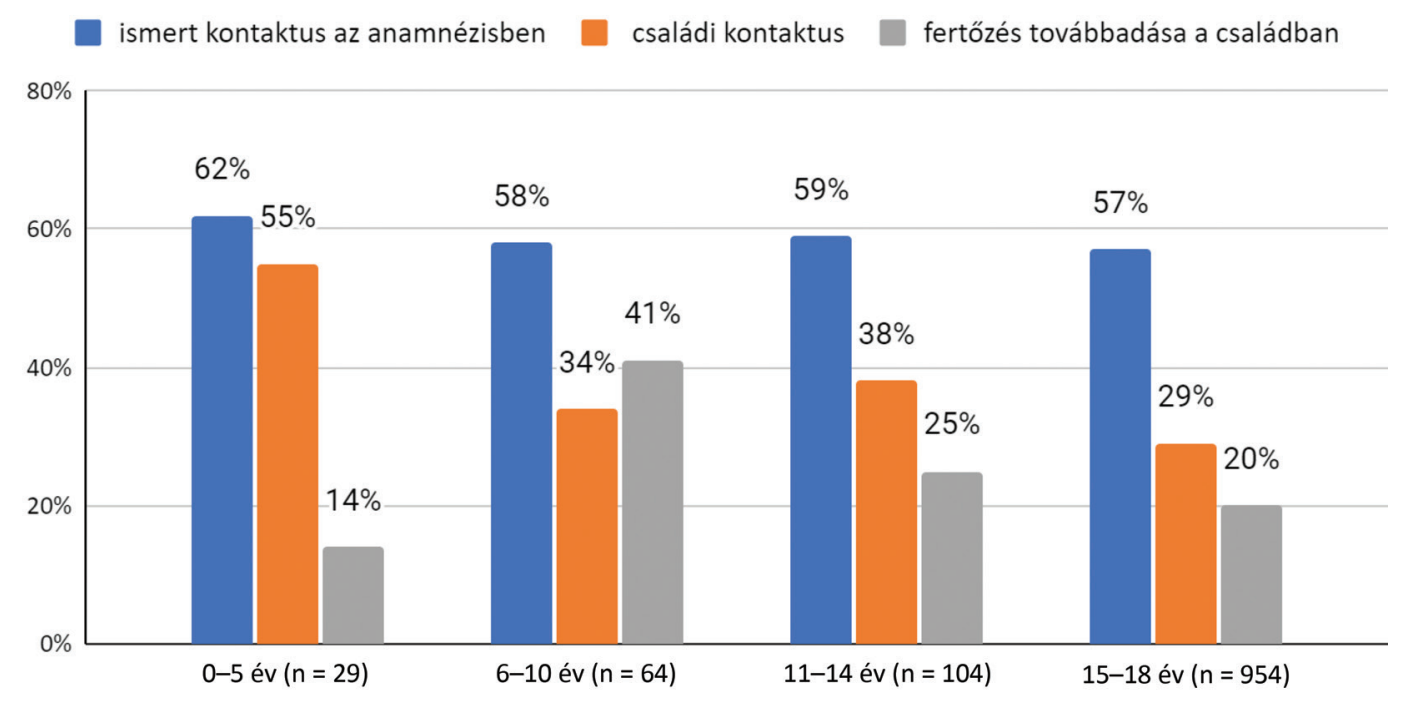

4. ábra

| Kontaktus és családon belüli továbbfertőzés korcsoportonként a 2. hullámban 


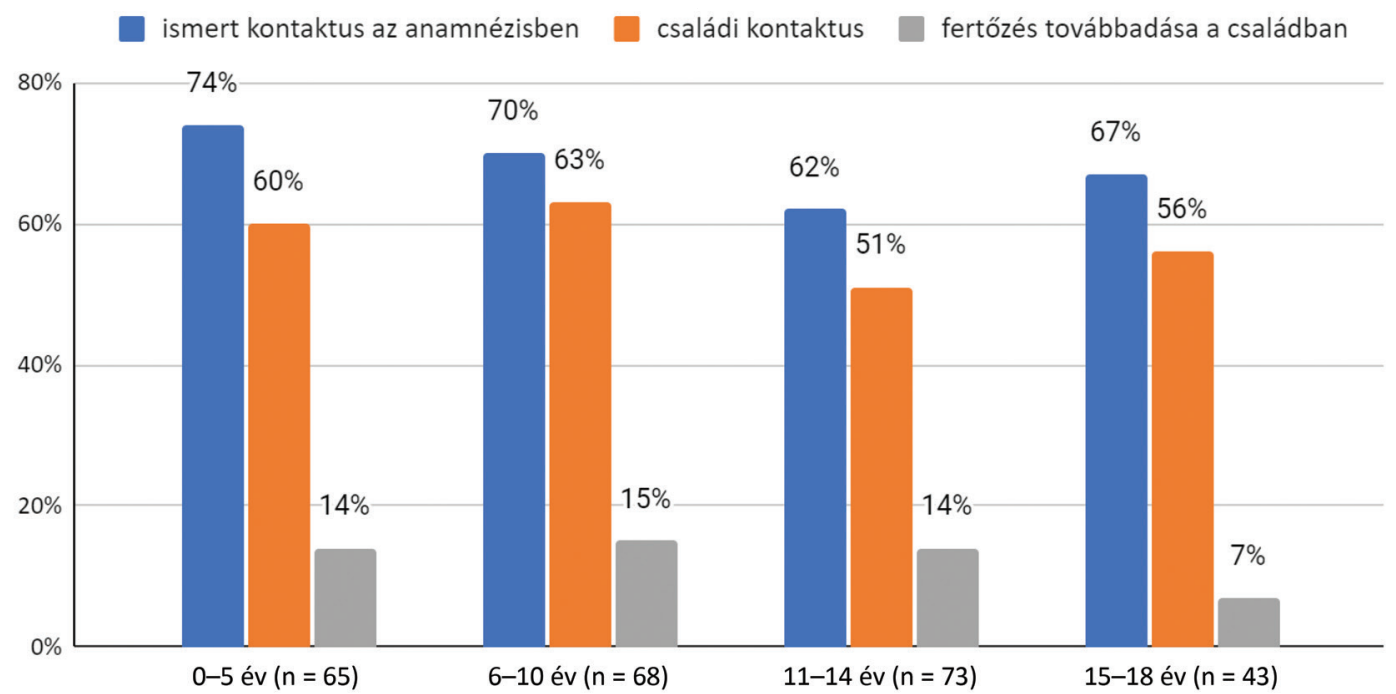

5. ábra $\quad$ Kontaktus és családon belüli továbbfertőzés korcsoportonként a 3. hullámban

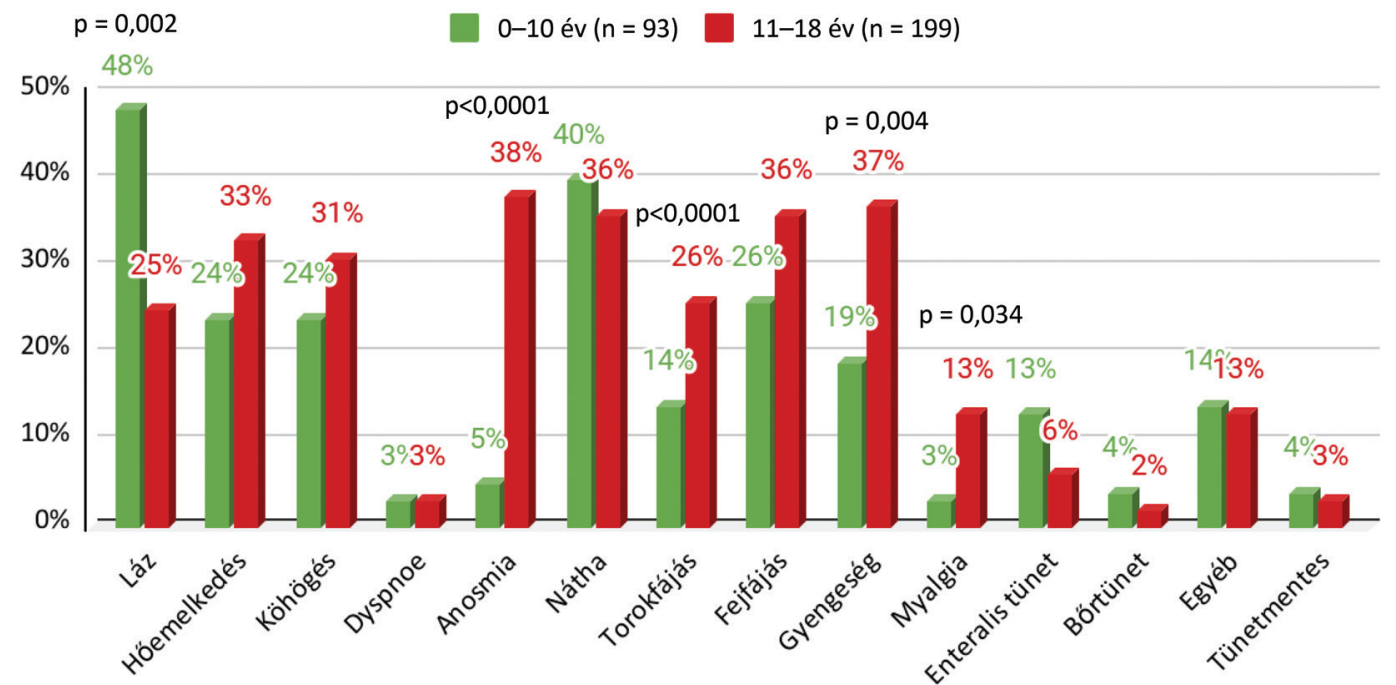

6. ábra | A tünetek gyakorisága a 0-10 éves és 11-18 éves korosztályban a 2. hullámban (szignifikáns különbség esetén a p-értéket is feltüntettük)

$0-10$ év $(n=133) \square 11-18$ év $(n=116)$

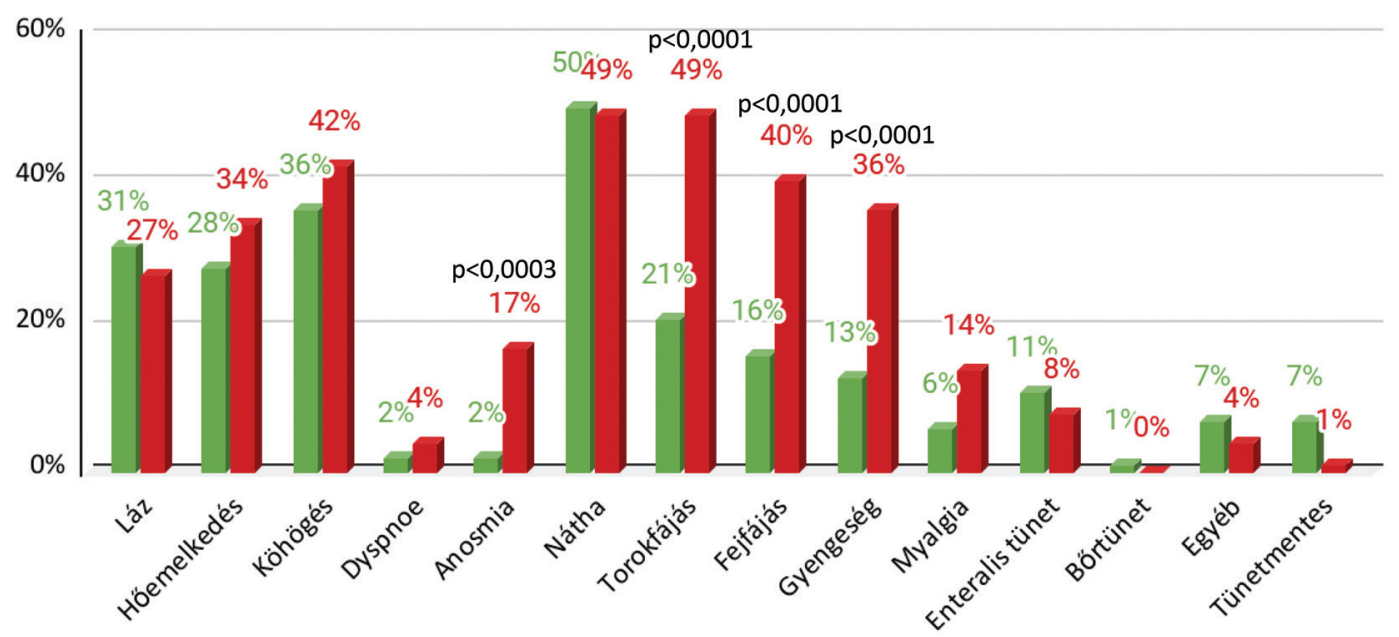

7. ábra |A tünetek gyakorisága a 0-10 éves és 11-18 éves korosztályban a 3. hullámban (szignifikáns különbség esetén a p-értéket is feltüntettük) 
2. hullám: a 0-10 éves és 11-18 éves korcsoport öszszevetésében láz szignifikánsan magasabb arányban fordult elő 10 éves kor alatt $(48 \%$ vs. $25 \%, \mathrm{p}=0,0027)$. További életkori bontásban a láz 5 éves kor alatt volt a leggyakoribb (57\%), az enteralis tünetek pedig a 6-10 évesek körében fordultak elő a leggyakrabban az összes korosztály közül (14\%). A 11-18 éves korcsoportban szignifikánsan magasabb volt a torokfájás (14\% vs. 26\%), a gyengeség (19\% vs. $37 \%)$, a myalgia (3\% vs. $13 \%)$ és a szaglászavar ( $5 \%$ vs. $38 \%)$ gyakorisága $(\mathrm{p}<0,05)$. Lényegesen nagyobb arányban fordult elő ebben a korosztályban a köhögés, a fejfájás és a hőemelkedés is (NS) (6. ábra).

3. hullám: a 11-18 éves korcsoportban szignifikánsan gyakoribb volt a torokfájás (21\% vs. $49 \%$ ), az anosmia ( $2 \%$ vs. $17 \%)$, a gyengeség ( $13 \%$ vs. $36 \%)$ és a fejfájás $(16 \%$ vs. $40 \%)$, mint a 10 év alattiakban $(\mathrm{p}<0,05)$. A láz közel egyenlő arányban, a betegek $\mathrm{kb}$. harmadában jelentkezett mindkét életkori csoportban (7. ábra). Kiemelendő, hogy ebben a hullámban a 2 . hullámhoz képest minden korosztályban emelkedett a felső légúti tünetek (köhögés, nátha, torokfájás) gyakorisága.

\section{Megbeszélés}

A COVID-19-pandémia 2. és 3. hullámában összesen 545 , az alapellátásban diagnosztizált és kezelt SARSCoV-2-fertőzött gyermek adatait dolgoztuk fel retrospektív tanulmányban, országszerte 12 praxis beteganyagát összegezve. Eredményeinket a nemzetközi publikációkkal összevetve az alábbi megfigyeléseket tettük.

A COVID-19-megbetegedés gyermekkori enyhe lefolyását tekintve első ellátóként a házi gyermekorvosok felelősek a betegek többségének felismeréséért és diagnosztizálásáért. Ennek eredményeként a Nemzeti Népegészségügyi Központ hazai statisztikája szerint 2020. december 13-ig az összes fertőzött 1,5\%-át a 10 év alatti korosztályban, míg a fertőzöttek 7,4\%-át a 10-19 éves korosztályban regisztrálták (283 870 igazolt megbetegedésből). Hasonlóak az ECDC eredményei is, amelyek alapján az összes európai fertőzött 3,8\%-a a 0-10 éves, 10,3\%-a pedig a 10-19 éves korosztályba tartozott, az első hullám 1-2\%-os gyakoriságával szemben [12]. Az incidencia emelkedése nemcsak a szélesebb körü teszteléssel magyarázható, hanem a 3. hullámban az alfa-variáns nagyobb fertőzőképessége is hozzájárulhatott a gyermekpopuláció magasabb érintettségéhez. Újabb mutánsok megjelenése a fertőzőképesség további növekedését okozhatja, ami - párosulva a 12-18 éves korosztály alacsony átoltottságával és a kisebbek számára még nem engedélyezett immunizációval - a jövőben tovább emelheti a gyermekkori fertőzések arányát [13].

Az életkori megoszlás vizsgálata a 2 . járványhullámban (2020. szeptembertől) a 10 év feletti korosztály magasabb arányát mutatta a megbetegedettek között (68\%), ami egyrészt nagyobb expozíciónak kitett életvitelükkel függhet össze, másrészt a 10 év alattiakban a tünetszegé- nyebb megjelenés miatt kevesebb esetet diagnosztizálhattunk. Adatainkban a 11-14 éves korosztály aránya volt a legmagasabb (36\%), szemben a CDC eredményeivel, ahol a 14-18 évesek domináltak. A 3. hullámban az életkori arányok megfordultak, a 10 évnél fiatalabbak domináltak (53\%), a 10 év felettiek aránya pedig 68\%-ról 47\%-ra csökkent. Az életkori megoszlás eltéréseit és változásait a középiskolák tartós bezárása magyarázhatja. A tünetek vonatkozásában a láz és a köhögés aránya a legtöbb publikált adat szerint 30-50\% a COVID-19-fertőzött gyermekpopulációban. Anyagunkban ez hasonló eredményeket adott, a nehézlégzés aránya 2-3\% volt. Életkori sajátosságok: a 2. hullámban a 10 év alatti populációban a láz, a nátha és a köhögés fordult elö a leggyakrabban, egyéb tünet ritkán jelentkezett (<25\%). A láz 5 éves kor alatt volt a leggyakoribb. A 10 év feletti korcsoportban a légúti tünetek mellett az általános tünetek aránya a $30-40 \%$-ot is elérte, és ebben a korcsoportban szignifikánsan magasabb volt a torokfájásnak, a szaglásízérzés zavarnak és az általános tüneteknek (fejfájás, gyengeség, myalgia) az aránya a 0-10 évesekhez képest. A 14-18 évesek mutatták a tünetek legszélesebb spektrumát. Ezek az életkori sajátosságok megfelelnek az irodalmi adatoknak, azzal a különbséggel, hogy anyagunkban a torokfájás, a nátha és a hőemelkedés nagyobb gyakorisággal fordult elő, mint a kb. 17000 és 12000 pediátriai beteg anyagát feldolgozó amerikai tanulmányokban, vélhetően az alapellátásban megforduló enyhe esetek nagyobb gyakorisága miatt $[6,14]$.

A 3. hullámban a betegség minden korosztályban közel egy nappal hosszabb lefolyást mutatott. Az alfa-variáns jellemzőjeként a nagyobb fertőzőképességgel és a magasabb víruskópiaszámmal összefüggésben az antigéngyorstesztek pozitivitása szignifikánsan megemelkedett, 31\%-ról 44\%-ra. Ebben a járványhullámban szignifikánsan magasabb arányban észleltünk légúti tüneteket (köhögést, náthát és torokfájást), míg az általános tünetek (fejfájás, gyengeség, izomfájdalom) aránya csökkent, a szaglászavar előfordulása pedig szignifikánsan alacsonyabb lett az előző hullámhoz képest. Mindez részben az életkori arányok megfordulásával, azaz a 10 év felettiek alacsonyabb arányával magyarázható, ugyanakkor az új vírusvariáns tünetképző tulajdonságai, a betegség patomechanizmusa is változhatott, mivel a nátha, a köhögés és a torokfájás tünete valamennyi korosztályban gyakoribbá vált. Járványhullámra jellemző, vírusvariáns okozta tünettani változást gyermekkorban mások is leírtak [15].

A tünetmentes gyermekek aránya irodalmi adatok szerint akár 30-50\% lehet [16]. Saját anyagunkban kb. 4\% volt, amit a tesztelési stratégia magyaráz (nem szúrőprogram része volt a vizsgálat, hanem tüneteket mutató és/vagy szoros kontaktusban levő gyermekeket vizsgáltunk). A hospitalizáció aránya $(0,18 \%)$ elmarad az irodalomban leírt 2-4\%-tól [7], vélhetően részben az alapellátásban látott enyhébb esetek dominanciája miatt, illetve az amerikai és angol adatok kiemelik az etnikai különbsé- 
geket a súlyosabb lefolyással összefüggésben (afroamerikaiak, mexikóiak, indiaiak esetében gyakoribb a súlyos kórkép), melyekkel nálunk nem kell számolni. Szövődményt $0,7 \%$-ban, illetve 3\%-ban találtunk a két hullámban. Ezen belül a MIS-C 3 gyermeket érintett az 545 fertőzöttből, ez a jelenlegi irodalmi adatokkal korrelál (<1\% a COVID-19-fertőzöttek között) [17].

A betegség akvirálása is mutatott életkori sajátosságokat: a 2. hullámban az 5 év alattiak nagyobb része (55\%) a szülőktől kapta el a betegséget, míg az 5-18 évesek közel 60-70\%-a közösségi kontaktust követően akvirálta a fertőzést (táborok, rendezvények, sportesemények). A 3. hullámban minden korosztály döntően családi közegben fertőződött meg (50-60\%), ami az ekkor fennálló járványügyi szigorításokkal, az óvoda- és iskolabezárásokkal magyarázható. Ekkor az iskolai/óvodai expozíció a felére csökkent ( $23 \%$ vs. $12 \%)$. Az irodalom igen nagy szórást mutat a családtagoktól akvirált fertőzés tekintetében (4-50\%); a nagy variabilitás részben az életkori sajátosságokkal, részben az aktuális korlátozó intézkedésekkel függhet össze [18]. Egy 77758 személyt vizsgáló metaanalízis a gyermekek családon belüli megfertőződését mindössze 17\%-nak találta a 2. hullámban [9].

A beteg gyermektől (index case) eredő, háztartáson belüli szekunder transzmisszió a 2 . hullámban 5 éves kor alatt volt a legalacsonyabb (14\%), míg az 5-10 éves korosztály fertőzte meg a leginkább a családtagokat (41\%). A 10 év feletti betegek $\mathrm{kb}$. negyede-ötöde adta át a fertőzést családon belül $(23 \%$, illetve $18 \%)$, amit a teljes vagy részleges otthoni elkülönítésük magyarázhat. A 3. hullámban a fertőzés továbbadása a családban igen alacsony arányú volt (7-15\%); mivel a gyermekek közel 60\%-ban a szülőktől/családtagoktól kapták el a fertőzést, nem volt kit továbbfertőzni, és vélhetően az otthoni óvintézkedések is jobban múködtek.

$\mathrm{Az}$ irodalomban megoszlanak a vélemények a 18 év alattiak szerepéről a fertőzés transzmissziója tekintetében: egyes tanulmányok a gyermekek alacsonyabb, mások magasabb fertőzőképességét találták. Egyetértés abban van, hogy a kisebb gyermekek kevésbé terjesztik a betegséget, illetve hogy a tünetekkel rendelkezők fertőzőbbek, mint a tünetmentesek, ahogy az a cseppfertőzéssel terjedő kórokozó esetében ismert [11, 19]. Az 5 év alattiak alacsonyabb fertőzőképessége összefügghet a tünetszegényebb megjelenéssel, esetleg az alacsonyabb ürített víruskópiaszámmal, bár a publikációk többsége a felnőttekéhez hasonló [20], sőt egyes tanulmányok azt meghaladó értékeket írnak le. A 15 év feletti, középiskolás korosztály fertőzőképessége ugyanakkor a saját korcsoportjukban jelentős lehet az életmódjuk és társasági szokásaik miatt, így ezt a korosztályt a szakirodalom is külön kezeli, körükben jelentős, egymás közötti vírusterjedéssel kell számolni.

Bár a közösségi terjedést nem vizsgáltuk, fontos megemlíteni az iskolák szerepét a járványterjedésben. Anyagunkban a két hullám között szignifikáns különbséget találtunk az expozíció vonatkozásában: az iskolai/óvodai kontaktusok aránya lényegesen csökkent (25\% vs. 12\%), bár az óvodák és az általános iskolák a 3. hullám csúcspontjáig nyitva tartottak. A legtöbb irodalmi adat arra utal, hogy az iskolalátogatás nem motorja a transzmissziónak, inkább a közösségi terjedéssel mutat korrelációt az iskolán belüli fertőzések aránya, követi a közösségben zajló tendenciákat [21, 22]. A korlátozó intézkedések betartása mellett járványgócokat igen ritkán írtak le iskolákban, ilyen esetekben a leginkább a maszkhasználat és a távolságtartás hiánya volt felelős a terjedésért. Ezért a legtöbb javaslat szerint az iskolák bezárása a korlátozó intézkedések között az utolsók között szerepel, figyelembe véve a gyermekek szociális igényeit és az online oktatás hátrányos pszichés hatásait. Az ECDC azonban felhívja a figyelmet arra, hogy a legtöbb ilyen tanulmány a 2. hullámban készült, a delta-variáns esetén nagyobb fokú terjedésre számíthatunk a gyermekek körében [23]. Emiatt az iskolák újraindításának része lehet a kiegészítő szürőprogramok bevezetése, főként a nem oltottak körében. A tünetmentesek szürésére az irodalom az antigéngyorsteszteket megfelelőnek találja (erre már nem invazív, nyálalapú tesztek is elérhetők), mivel kiszűrik a magas kópiaszámmal rendelkező, legfertőzóbb egyéneket a preszimptómás szakban és tünetmentes fertőzés esetén. A CDC adatai szerint a fertőzések kb. 50\%-a tőlük származik [24.]

Vizsgálatunk egyik korlátja, hogy nem folytattunk kiterjesztett kontaktkutatást; helyzetünkből adódóan a leginkább a háztartáson belüli terjedést vizsgáltuk, így a gyermekektől származó közösségi továbbterjedésről nincs adatunk. Másik limitáló tényező, hogy a betegek bevonása retrospektív módon történt, a tesztelés kritériumai, bár azonosak voltak a két hullámban és a praxisok között, mégis tartalmazhattak szubjektív tényezőket.

Publikációnk újszerûségét az adja, hogy az irodalomban megjelent tanulmányok többségétől eltérően nem kórházi esetek vagy sürgősségi osztályok eredményeit, hanem alapellátásban kezelt gyermekek adatait dolgoztuk fel, ami a COVID-19-megbetegedés szélesebb spektrumát mutatja be a tünettan és a betegség terjedése szempontjából, vizsgálva az életkori sajátosságokat és a két járványhullám különbségeit is.

\section{Következtetés}

Megállapítottuk, hogy (i) a klinikai kép korosztályonként eltéréseket mutat: 10 év alatt tünetszegényebb és főként felső légúti tünetek jelentkeznek, 10 év felett szignifikánsan magasabb az általános tünetek és az anosmia aránya. (ii) A 3. járványhullámban az életkori eloszlás megváltozott a 10 év alattiak javára, az iskolabezárások következtében. Ezzel párhuzamosan a tünetek előfordulása is módosult: szignifikánsan több légúti tünetet és kevesebb általános tünetet regisztráltunk, ami azonban a domináns alfa-variáns megváltozott tünetképzésével is összefügghet. (iii) A két járványhullámban változott az expozíció jellege: a 2. hullámban döntően 
közösségi kontaktus volt a fertőzés forrása, míg a 3. hullámban az esetek közel kétharmadában családi expozíció okozta a fertőzést. A háztartáson belüli szekunder transzmisszió mindkét hullámban alacsony volt, és a legkevésbé az 5 év alattiak, a leginkább a 6-10 évesek fertőzték meg a családtagokat.

Cikkünkkel arra is fel szeretnénk hívni a figyelmet, hogy az alapellátásnak továbbra is kiemelt szerepe van a járványgócok felszámolásában a korai tesztelés indikálásával, valamint a fertőzöttek és kontaktjaik izolációjának elrendelésével. A 18 év alatti korosztály széles körü védőoltási programja, a gyermekközösségek rendszeres szürése, valamint a gyermekekre adaptált védőintézkedések közösségekben történő fenntartása a jövőben fontos eszköze lehet a járványkezelésnek.

Anyagi támogatás: A szerzők a jelen közleménnyel kapcsolatos munkájukért semmilyen anyagi támogatásban nem részesültek.

Szerzői munkamegosztás: Valamennyi szerző részt vett az adatok gyűjtésében és feldolgozásában. O. B., S. A., E. H., K. K., Sz. B., D. G. és T. D. részt vett a közlemény megírásában. A cikk végleges változatát valamenynyi szerző elolvasta és jóváhagyta.

Érdekeltségek: A szerzőknek nincsenek érdekeltségeik.

\section{Irodalom}

[1] Centers for Disease Control and Prevention. COVID data tracker. Demographic trends of COVID-19 cases and deaths in the US reported to the CDC. CDC, Atlanta, GA. Available from: https://covid.cdc.gov/covid-data-tracker/\#demographics [accessed: August 13, 2021].

[2] European Centre for Disease Prevention and Control. An agency of the European Union. Data on the 14-day age-specific notification rate of new COVID-19 cases. ECDC, Stockholm. Available from: https://www.ecdc.europa.eu/en/publications-data/ covid-19-data-14-day-age-notification-rate-new-cases [accessed: August 13, 2021].

[3] Viner RM, Mytton OT, Bonell C, et al. Susceptibility to SARSCoV-2 infection among children and adolescents compared with adults: a systematic review and meta-analysis. JAMA Pediatr. 2021; 175: 143-156.

[4] Tönshoff B, Müller B, Elling R, et al. Prevalence of SARS-CoV-2 infection in children and their parents in Southwest Germany. JAMA Pediatr. 2021; 175: 586-593.

[5] Hyde Z. Difference in SARS-CoV-2 attack rate between children and adults may reflect bias. Clin Infect Dis. 2021 Feb 26. Doi: $10.1093 / \mathrm{cid} / \mathrm{ciab} 183$. [Epub ahead of print]

[6] Stokes EK, Zambrano LD, Anderson KN, et al. Coronavirus disease 2019 case surveillance - United States, January 22-May 30, 2020. Morb Mortal Wkly Rep. 2020; 69: 759-765.

[7] Kim L, Whitaker M, O'Halloran A, et al. Hospitalization rates and characteristics of children aged $<18$ years hospitalized with laboratory-confirmed COVID-19 - COVID-NET, 14 States, March 1-July 25, 2020. Morb Mortal Wkly Rep. 2020; 69: $1081-1088$
[8] Somekh E, Gleyzer A, Heller E, et al. The role of children in the dynamics of intra family coronavirus 2019 spread in densely populated area. Pediatr Infect Dis J. 2020; 39: e202-e204.

[9] Madewell ZJ, Yang Y, Longini IM Jr, et al. Household transmission of SARS-CoV-2: a systematic review and meta-analysis. JAMA Netw Open 2020; 3: e2031756.

[10] Zhu Y, Bloxham CJ, Hulme KD, et al. A meta-analysis on the role of children in severe acute respiratory syndrome coronavirus-2 in household transmission clusters. Clin Infect Dis. 2021; 72: el146-el153.

[11] Soriano-Arandes A, Gatell A, Serrano P, et al. Household SARSCoV-2 transmission and children: a network prospective study. Clin Infect Dis. 2021 Mar 12. Doi: 10.1093/cid/ciab228. [Epub ahead of print]

[12] European Centre for Disease Prevention and Control. Weeklysurveillance-report on COVID-19. ECDC, Stockholm, Week 27, 2021. Available from: https://www.ecdc.europa.eu/en/ covid-19/surveillance/weekly-surveillance-report [accessed: August 13, 2021].

[13] Brookman S, Cook J, Zucherman M, et al. Effect of the new SARS-CoV-2 variant B.1.1.7 on children and young people. Lancet Child Adolesc Health 2021; 5: e9-e10.

[14] Parcha V, Booker KS, Kalra R., et al. A retrospective cohort study of 12,306 pediatric COVID-19 patients in the United States. Sci Rep. 2021; 11: 10231.

[15] Chua GT, Wong JS, Lam I, et al. Clinical characteristics and transmission of COVID-19 in children and youths during 3 waves of outbreaks in Hong Kong. JAMA Netw Open 2021; 4: e218824.

[16] Oran DP, Topol EJ. The proportion of SARS-CoV-2 infections that are asymptomatic: a systematic review. Ann Intern Med. 2021; 174: 655-662.

[17] Dufort EM, Koumans EH, Chow EJ, et al. Multisystem inflammatory syndrome in children in New York State. N Engl J Med. 2020; 383: 347-358.

[18] Goldstein E, Lipsitch M, Cevik M. On the effect of age on the transmission of SARS-CoV-2 in households, schools, and the community. J Infect Dis. 2021; 223: 362-369.

[19] Pitman-Hunt C, Leja J, Jiwani ZM, et al. SARS-CoV-2 transmission in an urban community: the role of children and household contacts. J Pediatric Infect Dis Soc. 2020 Nov 27. Doi: 10.1093/ jpids/piaal58. [Epub ahead of print]

[20] Madera S, Crawford E, Langelier C, et al. Nasopharyngeal SARS-CoV-2 viral loads in young children do not differ significantly from those in older children and adults. Sci Rep. 2021; 11: 3044

[21] Yung CF, Kam KQ, Nadua KD, et al. Novel coronavirus 2019 transmission risk in educational settings. Clin Infect Dis. 2021; 72: 1055-1058.

[22] Zimmerman KO, Akinboyo IC, Brookhart MA, et al. Incidence and secondary transmission of SARS-CoV-2 infections in schools. Pediatrics 2021; 147: e2020048090.

[23] Centers for Disease Control and Prevention. COVID-19 in children and the role of school settings in transmission - second update. CDC, Atlanta, GA, 21 Jul 2021. Available from: https://www.ecdc.europa.eu/en/publications-data/childrenand-school-settings-covid-19-transmission [accessed: August $13,2021]$.

[24] Centers for Disease Control and Prevention. Science brief: transmission of SARS-CoV-2 in K-12 schools and early care and education programs. CDC, Atlanta, GA; updated: July 9, 2021. Available from: https://www.cdc.gov/coronavirus/2019ncov/science/science-briefs/transmission_k_12_schools.html [accessed: August 13, 2021].

(Karászi Éva dr.,

Budapest, Káldor Adolf u. 3-5., 1221 e-mail: evakaraszi121@gmail.com)

A cikk a Creative Commons Attribution 4.0 International License (https://creativecommons.org/licenses/by-nc/4.0/) feltételei szerint publikált Open Access közlemény. 